\title{
NĚKOLIK POZNÁMEK (NEJEN) K PENĚŽITÉ NÁHRADĚ PŘI VÝKONU PRÁCE MIMO PRACOVIŠTĚ ZAMĚSTNAVATELE*
}

\author{
JAKUB MORÁVEK**
}

\begin{abstract}
A Few Notes on (Not Only) Monetary Compensation for Performing Work outside the Employer's Workplace

The paper is focused on a few notes on (not only) monetary compensation for performing work outside the employer's workplace. The author critically evaluates the current legislation and presents considerations de lege ferenda.
\end{abstract}

Keywords: labour law; home working; compensation for home working

Klíčová slova: pracovní právo; výkon práce z domova; náhrada při výkonu práce z domova

DOI: $10.14712 / 23366478.2021 .11$

Mnozí doufají, že stávající neutěšená situace brzy odezní a vrátíme se do světa před únorem 2020. Do světa, v němž budeme nerušeně a bezstarostně pokračovat ve svých tehdejších životech. Nechci být špatným prorokem, ale v tuto chvíli není žádný rozumný důvod se domnívat, že se něco takového v dohledné době stane. Virus (doufejme snad) nakonec udoláme. Je však stále více evidentní, že cena bude vysoká. Vedle lidských ztrát se zpožděním dorazí hospodářské důsledky, které mohou být v určitých oblastech zdrcující.

Například cizinecký ruch a na něj navázaná odvětví. Je bláhové domnívat se, že dojde k jeho obnovení v intenzitě odpovídající roku 2019. To nenastane letos, ani příští rok a zřejmě ještě ani řadu let poté. ${ }^{1}$

Taková perspektiva nutně vede k úvahám, zda bude na uvolnění relativně značného množství pracovních sil schopen odpovídajícím způsobem reagovat systém zaměstnanosti, resp. zda se souvisejícími efekty počítají veřejné rozpočty a systém sociálního zabezpečení, a to nejen po příjmové stránce. S přihlédnutím $\mathrm{k}$ fungování dotčených

\footnotetext{
* Tento článek zohledňuje právní stav k 31.3. 2021 a vznikl díky podpoře poskytované v rámci výzkumného projektu Soukromé právo a výzvy dneška, id. č. PROGRES Q03, a projektu UNCE/HUM/034 Závislá práce v 21. století - otázky a výzvy na Právnické fakultě Univerzity Karlovy.

** Autor působí na katedře pracovního práva a práva sociálního zabezpečení Právnické fakulty Univerzity Karlovy jako docent a tajemník. Je místopředsedou České společnosti pro pracovní právo a právo sociálního zabezpečení a advokátem v Praze.

1 O důsledcích, které může přivést dlouhodobé uzavření škol a sociální distanc dětí, se nechce ani uvažovat.
} 
systémů v období před únorem 2020 a ke stávajícímu stavu veřejných financí jsou tyto otázky více než aktuální a naléhavě volají po rychlém a efektivním řešení.

Zdá se však, jako by zůstávaly zcela mimo pozornost politické reprezentace. Nelze se zbavit dojmu, že s vysokou mírou pravděpodobnosti tak bude konečné hodnocení znít ,zase pozdě“.

Cílem však není zde mudrovat a psát černé scénáře. Účelem tohoto př́ísp̌vku je ve vybraných oblastech pracovněprávní legislativy naznačit a zdůvodnit možná řešení, včetně úvah de lege ferenda.

Pandemie přese všechno přinesla z určitého úhlu pohledu i určité pozitivní momenty.

$\mathrm{Z}$ hlediska pracovněprávních vztahů rozvinula některé prozatím méně využívané způsoby výkonu práce, zejména došlo $\mathrm{k}$ intenzivnějšímu zapojení moderních technologií a pracovní proces se tak v určitých oblastech více přiblížil technologické realitě 21. století.

Zaměstnavatelé reagovali zpravidla pružně. Avšak v okamžiku, kdy začali zjišstovat zákonný podklad pro přenesení kancelárí do obývacích pokojů, pracoven a ložnic svých zaměstnanců a později zákonný podklad pro vyhovění krizovým opatřením vlády, která jim ukládala využívat práci na dálku, narazili, jako již mnohokrát dříve, na hluché místo.

Již řadu let je přitom částí odborné veřejnosti upozorňováno, ${ }^{2}$ že stávající právní úprava není pro výkon práce mimo pracoviště zaměstnavatele z řady hledisek dostatečná (nejméně pokud jde o pravidla organizace práce, o řešení odpovědnosti, včetně odpovědnosti za pracovní úrazy a nemoci z povolání, o bezpečnost a ochranu zdraví při práci, o ochranu dat a osobních údajů, o kompenzaci nákladů vznikajících při výkonu práce mimo pracoviště zaměstnavatele). Reakce zákonodárce, resp. ministerstva práce a sociálních věcí, na tyto hlasy nebyla prozatím v podstatě žádná. Stejné platí i pro období roku 2020, kdy byla potřeba doplnění právní úpravy evidentní a neoddiskutovatelná; pro rok 2020 budiž však ministerstvu částečnou omluvou, že byla k řešení celá řada dalších problémů.

Doufejme, že až se nynější situace zklidní, dnes již empiricky ověřený fakt nezapadne a nenastane oblíbené schéma řešení problémů pracovněprávní legislativy, které lze stručně charakterizovat jako „lepší nežli řešení, je zaryté mlčeni““.

Věřme, že bude hledáno konstruktivní a efektivní řešení. Jeho předpokladem, což je mj. zjevné v kontextu aplikačních problémů, které lze předpokládat u poslední novely zákoníku práce, ${ }^{3}$ přitom musí být široká diskuse se zástupci zejména aplikační praxe. Opakovaně se totiž potvrdilo, že kabinetně vytvářená legislativa při praktické aplikaci funguje spíše náhodou.

$\mathrm{Na}$ jiných místech byla v obecné rovině věnována pozornost problematickým momentům stávající právní úpravy, jde-li o výkon práce prostřednictvím moderních

2 Blíže viz např́íklad MORÁVEK, J. Změna některých výchozích sociálních paradigmat a její reflexe v právní úpravě pracovněprávních vztahů a sociálního zabezpečení. Právník. 2021, č. 2, s. 136-141; BARANCOVÁ, H. (ed.). Pracovné právo v digitálnej dobe. Praha: Leges, 2017; BARANCOVÁ, H. Nové technológie v pracovnom práve a bezpečnost' a ochrana zdravia pri práci. Praha: Leges, 2017; OLŠOVSKÁ, A. (ed.). Pracovné podmienky zamestnancov v období štvrtej priemyselnej revolúcie. Praha: Leges, 2018.

3 Srov. např́íklad MORÁVEK, J. Novela zákoníku práce, aneb jak se to (ne)povedlo. Právní rozhledy. 2020, č. 13-14, s. 488-494; či MORÁVEK, J. K některým (nejen) problematickým otázkám dovolené po 1. 1. 2021. Právní rozhledy. 2021, č. 2, s. 59 a násl. 
technologií, zejména při výkonu práce na dálku. ${ }^{4}$ Předložený příspěvek, vycházeje $\mathrm{z}$ dřívějších tezí a komentářo̊, se zaměřuje na některé dílčí aspekty této materie. Konkrétně je věnován výchozím předpokladům pro výkon práce na dálku, náhradě nákladů při výkonu práce na dálku a důsledkům doporučení a povinnosti využívat distanční výkon práce ve smyslu krizových opatření vydaných Vládou České republiky v době nouzového stavu.

\section{PRÁCE MIMO PRACOVIŠTĚ ZAMĚSTNAVATELE - POJMOVÉ VYMEZENÍ}

Ve veřejném prostoru se vžil pro situaci, kdy zaměstnanec nevykonává práci z pracoviště zaměstnavatele, nýbrž ji koná např́k lad ve svém bydlišti nebo na jiném obdobném dohodnutím místě, zjednodušující pojem home working.

Podle stávajícího zákonného režimu lze rozlišit několik pozic, pro které se označení home working používá.

$\mathrm{S}$ ohledem na tematické zaměření příspěvku bude dále věnována pozornost $\mathrm{z}$ celé širre situací připadajících v úvahu pozornost primárně té, kdy zaměstnanec pro přechodnou dobu namísto pracoviště zaměstnavatele vykonává práci ve svém bydlišti.

Pojem pracoviště zaměstnavatele není oproti bydlišti (viz ust. § 80 zákona č. 89/2012 Sb., občanský zákoník ${ }^{5}$ ) zákonem nijak definován. Jeho obsahové vymezení však lze dovodit z judikatury vysokých soudi̊.

Nejvyšší soud pojem pracoviště dlouhodobě vykládá (viz např́iklad ve věci sp. zn. 21 Cdo 4596/2014) jako „,místo, kde zaměstnanec plní podle pokynů zaměstnavatele své pracovní úkoly; okruh těchto míst, v nichž může zaměstnavatel pridělovat zaměstnanci práci, je dán vymezením místa výkonu práce v pracovní smlouvě“. Tuto definici lze doplnit ust. § 274a zákona č. 262/2006 Sb., zákoník práce, ${ }^{6}$ a judikaturou vztahující se k odpovědnosti zaměstnavatele za pracovní úrazy (viz například Nejvyšší soud ve věci sp. zn. 21 Cdo 1824/2005).

Na základě vzájemného prolnutí pak lze „pracovištěm zaměstnavatele“ rozumět „zaměstnavatelem určené místo, v rámci místa výkonu práce zaměstnance sjednaného v pracovní smlouvě, ke kterému svědči zaměstnavateli dispoziční oprávnění (je v rámci sféry jeho vlivu), a na kterém zaměstnanec obvykle vykonává přidělené pracovní úkoly “.

Stávající pracovněprávní legislativa v základu nabízí tyto právní režimy:

a) zaměstnanec vykonává práci na pracovišti zaměstnavatele v pracovní době rozvržené zaměstnavatelem. Tento režim zahrnuje i flexibilní způsoby rozvržení pracovní doby, jako je pružné rozvržení pracovní doby a konto pracovní doby;

b) zaměstnanec vykonává práci mimo pracoviště zaměstnavatele v pracovní době rozvržené zaměstnavatelem. Tento režim zahrnuje i flexibilní zpơsoby rozvržení pracovní doby, jako je pružné rozvržení pracovní doby a konto pracovní doby;

4 Srov. například MORÁVEK, J. Změna některých výchozích sociálních paradigmat a její reflexe v právní úpravě pracovněprávních vztahů a sociálního zabezpečení. Právník. 2021, č. 2, s. 136-141.

5 Dále jen „ObčZ“".

6 Dále jen „ZPr“. 
c) zaměstnanec vykonává práci mimo pracoviště zaměstnavatele v pracovní době, kterou si rozvrhuje sám, a podle dohodnutých podmínek. Jedná se o institut zavedený ust. $§ 317$ ZPr.

Režimy podle písm. b) a c) jsou si v mnohém podobné. Je zde však nezanedbatelný rozdíl v právech a povinnostech na úseku rozvržení pracovní doby, příplatků k práci, přesčasové práce a překážek v práci.

Uvedené rozlišení není pro širokou škálu charakterově odlišných druhů práce, které ve vztahu k jednotlivým režimům přichází v úvahu, dostačující.

Klasifikaci ve smyslu bodů a) až c) je tak třeba předřadit kritérium charakteru vykonávané práce. To umožňuje rozlišit tři základní pozice, třri skupiny zaměstnanců:

i. zaměstnance, jejichž druh práce z povahy věci předpokládá výkon práce mimo pracoviště zaměstnavatele, zaměstnance, kteří práci nevykonávají pravidelně na jednom místě - typicky řidiči, obchodní zástupci atd.

ii. Zaměstnance vykonávající práci, která se obvykle vykonává na pracovišti zaměstnavatele, jejíž charakter však nevylučuje, že může být vykonána i na jiném dohodnutém místě mimo sféru vlivu zaměstnavatele (například v bydlišti zaměstnance), přičemž k jejímu výkonu se využívají zpravidla obvykle dostupné pracovní prostředky - typicky běžná agenda zpracovávaná prostřednictvím PC za využití internetu odpovídající pracovní náplni druhu práce fakturant nebo mzdový účetní.

iii. Zaměstnance vykonávající práci, jejíž charakter neumožňuje výkon práce na místě odlišném od pracoviště zaměstnavatele, jako je vrátný, tovární dělník v pásové výrobě atp.

$\mathrm{S}$ ohledem na možnou kombinaci a) až c) u jediného zaměstnance, zejména u zaměstnanců pracujících s výpočetní technikou, ${ }^{7}$ musí být za primární vzato rozlišení podle předchozího odstavce a až následně rozlišení v intencích a) až c).

Formálně pojmově přitom jednotlivé režimy v právní úpravě rozlišeny nejsou. Jejich (stejně jako škály dalších tak, aby byly pokryty základní typové situace) konkretizace a výslovná deklarace se přitom zdá pro budoucí změnu právní úpravy (má-li být právní úprava přizpůsobena potřebám aplikační praxe) nezbytná. Výslovné odlišení umožní vést jasnou dělicí linii, jde-li o odlišná práva, povinnosti a další podmínky toho kterého režimu.

Vytvoření více typizovaných pracovních režimů je dáno neudržitelností stávajícího stavu, kdy při oslabení organizačních prvků (určení času či místa výkonu práce) zůstává nezměněna intenzita působení ochranného zákonodárství, zejména odpovědnostní instituty navázané na zaměstnavatele. ${ }^{8}$

Dále bude věnována pozornost primárně práci/zaměstnanci odpovídajícímu kategorizaci ii.), který by měl vykonávat po přechodnou dobu práci mimo pracoviště zaměstnavatele ve svém bydlišti, tedy zaměstnanci odpovídajícímu kategorizaci podle bodu ii.), písm. b) a c).

7 Všechny režimy je možné kombinovat, tzn. jeden zaměstnanec může vykonávat práci v určité dny na pracovišti zaměstnavatele, ve zbytku týdne mimo pracoviště zaměstnavatele s tím, že po část svého úvazku bude $\mathrm{v}$ režimu b) a ve zbytku v režimu c).

8 Při pojmovém vymezení jednotlivých kategorií by se měla taktéž zohlednit délka, po kterou by měl zaměstnanec práci v jednotlivých režimech konat. 


\section{DOHODA O VÝKONU PRÁCE MIMO PRACOVIŠTĚ ZAMĚSTNAVATELE}

Žádný právní předpis zaměstnanci nepřiznává právo si vůči zaměstnavateli výkon práce mimo pracoviště zaměstnavatele jednostranně vymínit. $Z$ druhé strany bez dohody se zaměstnancem nelze zaměstnanci výkon práce mimo pracoviště, zejména pak z jeho bydliště, nařídit. To platí i v případě, kdy se nachází místo, kde by měla být práce vykonána, $v$ rámci místa výkonu práce zaměstnance. Důvodů je několik.

Souhrnně a zjednodušeně řečeno je překážkou nařízení výkonu práce $v$ bydlišti, které se nachází v rámci místa výkonu práce zaměstnance, právo na soukromí a domovní svoboda zaměstnance, př́íp. se zaměstnancem spolužijících osob. Vedle toho se jedná o absenci dispozičního oprávnění zaměstnavatele k prostoru, kde by měla být práce vykonávána (a věcí v něm), a spolu s tím o právo na ochranu majetku zaměstnance, př́íp. třetí osoby, která nese náklady na užívání prostor a věcí v nich. Dotčení třetích osob, tedy osob společně žijících se zaměstnancem, příp. osob nesoucích náklady související $\mathrm{s}$ užíváním prostor a věcí $\mathrm{v}$ nich, je jedním z nejzávažnějších problémů, který je však často přehlížen a v aplikační praxi nijak řešen (viz níže).

Podkladem pro výkon práce $\mathrm{z}$ bydliště, resp. mimo pracoviště zaměstnavatele, je tudíž dohoda. To platí i v době pandemie, kdy je využívání distančního způsobu práce zaměstnavatelům uloženo (viz níže).

Zákon pro dohodu nepředepisuje žádnou formu. Kvůli právní jistotě, ale i kvůli př́ípadnému obsahu (viz písm. ii. níže), se však písemné formě lze jen obtížně vyhnout.

Předpokladem platnosti dohody je (vedle svobodné vůle jednajících) právní i faktická možnost výkonu práce v bydlišti zaměstnance. To úzce souvisí s obsahem dohody.

Dohoda má několik podstatných momentů, které v ní musí být, resp. měly by v ní být (případně ve vnitřním předpise na jejím základě), řešeny. Konkrétně se jedná nejméně o:

i. ujednání o výkonu práce mimo pracoviště zaměstnavatele, které mủže být následováno bližším vymezením podmínek takového výkonu práce (viz shora pravidla o rozvržení pracovní doby, povinnost stanoveným způsobem předem oznamovat, kdy bude práce vykonávána, pravidelné zasílání přehledu odpracované pracovní doby atd.) a pravidel organizace práce (způsob komunikace, zadávání pracovních úkolů a oznamování splnění pracovního úkolu atd.);

\section{ii. určení místa, ze kterého bude práce vykonávána.}

I s ohledem na scházející pardon, jde-li o povinnosti v oblasti bezpečnosti a ochrany zdraví při práci, a o odpovědnost za pracovní úrazy a nemoci z povolání a s ohledem na další následně nanesené argumenty, se nezdá vhodné zaměstnanci poskytnout větší míru volnosti v určení místa, odkud bude práce vykonávána.

Kvůli důsledkům plynoucím ze společného působení více právních řádů se nezdá být rozumné, aby místo, odkud bude práce vykonávána, bylo mimo území České republiky.

Pokud by se mělo jednat o místo mimo místo výkonu práce, mj. s ohledem na ust. $\S 40$ odst. $2 \mathrm{ZPr}$, je třeba alespoň na tuto přechodnou dobu rozšririt odpovídajícím způsobem místo výkonu práce zaměstnance. Dohoda o výkonu práce mimo 
pracoviště zaměstnavatele tak bude současně dohodou o změně místa výkonu práce.

Podmínkou platnosti dohody (mj. z hlediska právní možnosti plnění) je, aby výkonu práce v ujednaném místě nebránily předpisy veřejného práva (způsob kolaudace prostoru v kontextu charakteru práce a způsobu jejího výkonu), stejně jako soukromá práva třetích osob.

Spíše okrajový význam s ohledem na práce obvykle vykonávané v bydlišti má v tomto směru ust. $\$ 2255$ odst. 2 ObčZ.

Problematická je z hlediska aplikační praxe situace, kdy zaměstnanec nemá dostatečné oprávnění udělit svolení k užívání daného místa kvůli soukromým právům třetích osob. Vedle zásahu do osobnostní sféry třetích spolužijících osob se uvedeným míní zejména nedostatečné nebo případně zcela absentující dispoziční oprávnění zaměstnance k danému místu; zaměstnanec kupříkladu žije v partnerském vztahu s vlastníkem prostor, tzn. právem udělit svolení k jejich využívání pro výkon práce nedisponuje.

V takovém případě je podmínkou pro výkon práce $\mathrm{z}$ daného místa souhlas oprávněné osoby. V této části tudíž nejde o dohodu zaměstnance a zaměstnavatele, nýbrž zaměstnavatele a třetí osoby o tom, že zaměstnanec může prostor využít k výkonu práce pro zaměstnavatele.

Nebyla-li by za užívání prostor poskytována žádná úplata a poskytována by byla jen náhrada za jejich využití, jednalo by se o smlouvu o výpůjčce dle ust. 2193 an. ObčZ. Takovou smlouvu může zaměstnanec na základě plné moci uzavřít i v zastoupení oprávněného; takové řešení bude pravděpodobně nejpraktičtější.

iii. určení věcí neposkytnutých zaměstnavatelem $k$ výkonu práce, které budou $k$ výkonu práce využity, a o rozsah jejich využití.

Zde platí obdobně uvedené v předešlém bodě, včetně uvedeného v závěru ohledně nedostatečného dispozičního oprávnění zaměstnance k užívaným věcem a souvisejících smluvních vztahů.

iv. ujednání o zpusobu úhrady nákladi̊ za využití prostor, prostředků a služeb.

$\mathrm{S}$ přihlédnutím k obsahu odst. ii. a iii. by se mělo jednat o ujednání s příslušnou oprávněnou osobou, u níž došlo v důsledku výkonu práce ke snížení hodnoty majetku, specifikující, jakým způsobem a za jakých podmínek (předložení jaké dokumentace) bude náhrada vyplacena. V dalším viz následující bod 3 .

Komplexnost a složitost věci, jak byla naznačena, nereflektují smělci, zejména $\mathrm{z}$ řad zástupců zaměstnanců, kteří hovoří o zakotvení zákonného práva zaměstnance na jednostranné vymínění si výkonu práce z bydliště v zákonem definovaném rozsahu za týden. ${ }^{9}$ $\mathrm{V}$ této poloze by totiž, pokud bychom nepřistoupili na rozlišování mezi zaměstnanci nadanými dostatečným dispozičním oprávněním k místu a věcem potřebným k výkonu práce v jeho rámci a zaměstnanci bez potřebného oprávnění, uplatnění předmětného

9 O něčem takovém lze uvažovat pouze za předpokladu, že budou odpovídajícím způsobem komplexně a efektivně vyřešeny všechny shora zmíněné oblasti. A dále, i kdyby se tak stalo, bude zde otázka s podstatným hodnotovým momentem, konkrétně - proč má mít skupina zaměstnanců, z povahy věci těch, kteří nevykonávají fyzicky těžkou práci, výhodu oproti ostatním spočívající v tom, že si mohou z vlastního rozhodnutí vymínit vůči zaměstnavateli ještě větší pohodlí, tedy výkon práce ze svého bydliště. 
práva (v některých případech) současně znamenalo (vedle založení povinnosti případně strpět jisté narušení osobnostní sféry spolužijících osob) povinnost třetí osoby strpět využití svých prostor a věcí pro výkon práce zaměstnancem pro zaměstnavatele s tím, že náhradu nákladů vzniklých výkonem práce by si tato třetí osoba uplatňovala u zaměstnavatele. Taková právní úprava by v testu proporcionality mohla obstát jen stěží.

\section{VÝKON PRÁCE MIMO PRACOVIŠTĚ ZAMĚSTNAVATELE - BENEFIT I POVINNOST}

Při rozhodování/zvažování, zda zaměstnanci umožnit (po přechodnou dobu) práci z dohodnutého místa mimo pracoviště zaměstnavatele, by měly být důsledně váženy zejména tyto podmínky a předpoklady:

- schopnosti zaměstnance - zda lze spoléhat na to, že zaměstnanec bude při výkonu práce mimo př́mý dohled zaměstnavatele efektivní, zda bude plnit své pracovněprávní povinnosti a práci v potřebné kvalitě a ve stanovených termínech vykoná;

- možnosti zaměstnance, zejména technické vybavení a další vybavení v místě výkonu práce - zda lze důvodně předpokládat, že je možné prostřednictvím poskytnutého vybavení, příp. vybavení v místě výkonu práce, práci řádně vykonat;

- charakter vykonávané práce - zda lze danou práci s ohledem na způsob jejího provádění, ale i s ohledem na potřebnou míru účasti dalších zaměstnanců a zpưsob komunikace mezi nimi, řádně vykonat mimo pracoviště zaměstnavatele, resp. v bydlišti zaměstnance;

- efektivnost a rentabilita výkonu práce mimo pracoviště zaměstnavatele, zejména s ohledem na dodatečné náklady na takovou práci (viz bod 4).

Jiné aspekty, není-li dále stanoveno jinak, by neměly být podkladem pro rozhodnutí o umožnění výkonu práce z domova; vždy je třeba dbát na zákaz diskriminace a zásadu rovného zacházení.

Na jaře 2020 byl distanční výkon práce epidemiology a politickou reprezentací doporučován při veřejných vystoupeních. V rámci podzimní indexace rizika hrozby šíření nákazy se využívání práce na dálku objevilo ve vládním usnesení nejdříve jako doporučení a následně i jako povinnost.

Dle čl. III usnesení Vlády České republiky ze dne 26. 10. 2020 č. 1102, o př́ijetí krizového opatření, vláda s účinností ode dne 28. října 2020 od 00:00 hod. nařídila „zaměstnavateliom využivat práci na dálku, pokud ji zaměstnanci mohou vzhledem $k$ charakteru práce a provozním podmínkám vykonávat v místě bydliště “. Stejné opatření bylo zopakováno později v prosinci 2020.

Je-li využívání distanční práce doporučeno, resp. nařízeno, je při vyhodnocování možnosti umožnění výkonu distanční práce třeba vycházet primárně a v podstatě výlučně z charakteru práce (charakterově nelze práci mimo pracoviště vykonat např́íklad při pásové tovární výrobě, stejně tak nelze mimo pracoviště zaměstnavatele vykonat práci ostraha objektu, stejně tak nebude možné vykonat z bydliště práci vyžadující vysokou míru zabezpečení dat, kterou není možné zaručit mimo pracoviště zaměstnavatele atd.) a z provozních podmínek na straně zaměstnance a zaměstnavatele (zda technické 
vybavení a další potřebné podmínky pro výkon práce, např́ílad kvalita internetového připojení $\mathrm{v}$ daném místě, výpočetní výkon zařízení zaměstnance nebo přenosného vybavení zaměstnavatele, umožňuje práci mimo pracoviště vykonat) namísto shora uvedeného širokého okruhu všemožných hledisek.

Jak povinnost, tak doporučení využívat distanční práci, plyne-li tak z vládního nařízení vyhlášeného v reakci na pandemickou situaci, lze (do jisté míry) v kontextu ust. $\S 102$ ZPr považovat za opatření $\mathrm{k}$ zajištění bezpečnosti a ochrany zdraví při práci.

Pokud by zaměstnanci nebyla distanční práce umožněna, byt' by s ohledem na její charakter a na provozní důvody bylo možné ji umožnit, a u zaměstnance by prokazatelně došlo na pracovišti či prŕípadně při přepravě z a na pracoviště ${ }^{10} \mathrm{k}$ nákaze covidem-19, není vyloučena odpovědnost zaměstnavatele za způsobenou újmu; vyjma poskytovatelů zdravotních služeb si lze jen obtížně představit kvalifikaci onemocnění covid-19 jako nemoci z povolání (navíc ani pozitivita na covid-19 a splnění tzv. hygienické podmínky nestačí - přítomny musí být i manifestní příznaky onemocnění), ${ }^{11}$ tzn. náhrada újmy by nebyla kryta zákonným pojištěním zaměstnavatele a $\mathrm{k}$ její úhradě by byl povinen př́ímo zaměstnavatel na základě ust. § $265 \mathrm{ZPr}{ }^{12}$

Vedle toho, s ohledem na podmínky dotačních programů (Antivirus atp.), může neumožnění výkonu distanční práce $\mathrm{v}$ tomto případě mít za důsledek odejmutí podpory, resp. založení povinnosti podporu vrátit.

Šîrení nákazy v rámci pracoviště v takové situaci (neumožnění využívání distanční práce, byt' to je s ohledem k okolnostem možné) by bylo také možné (za určitých podmínek) kvalifikovat jako trestný čin šîrení nakažlivé lidské nemoci z nedbalosti ve smyslu ust. § 153 t. z. Za tento trestný čin může být stíhána i právnická osoba.

Jinak řečeno, je-li součástí krizových opatření doporučení nebo přímo povinnost využívat distanční výkon práce, je třeba důsledně zvážit, v kterých př́ípadech je výkon práce mimo pracoviště zaměstnance možný. Je-li výkon práce z domova možný, je třeba zaměstnanci takový výkon práce nabídnout, příp. uložit, byla-li dříve uzavřena dohoda o možném jednostranném nařizování výkonu práce mimo pracoviště zaměstnavatele. Nabídku k výkonu práce, příp. pokyn k výkonu práce mimo pracoviště, jakož i případné odmítnutí ze strany zaměstnance je vhodné zdokumentovat kvůli ochraně oprávněných zájmů zaměstnavatele (vyvinění se v př́ípadě širrení nemoci na pracovišti z př́ípadné odpovědnosti za způsobenou újmu či trestnou činnost ve shora uvedeném

10 S ohledem na specifičnost situace lze v tomto případě uvažovat i o překonání ust. $\$ 274$ ZPr. Takové řešení se zdá být pro zaměstnance příznivější alternativou nežli pozice, že pokyn k výkonu práce na pracovišti je za této situace v rozporu se zákonem, zaměstnanec se do zaměstnání tudíž dostavit nemusí, nejde tak z jeho strany o porušení pracovní kázně a vůči zaměstnanci se uplatňuje překážka v práci na straně zaměstnavatele podle ust. $208 \mathrm{ZPr}$, včetně práva na náhradu mzdy nebo platu ve výši $100 \%$ průměrného výdělku.

11 V této souvislosti viz Informace Ministerstva zdravotnictví k uznávání onemocnění Covid-19 za nemoc z povolání. In: Ministerstvo zdravotnictví České republiky [online]. 20. 11. 2020 [cit. 2021-02-23]. Dostupné na: https://koronavirus.mzcr.cz/informace-ministerstva-zdravotnictvi-k-uznavani -onemocneni-covid-19-za-nemoc-z-povolani/.

12 Na druhou stranu založení odpovědnosti zaměstnavatele za škodu podle ust. $\S 265$ ZPr by v tomto případě předpokládalo prokázání (a) porušení právní povinnosti, (b) vznik škody, (c) příčinnou souvislost, tzn. že u zaměstnance došlo $\mathrm{k}$ nákaze při plnění pracovních úkolů nebo $\mathrm{v}$ přímé souvislosti s plněním pracovních úkolů v důsledku porušení předmětné právní povinnosti. V kontextu stávající pandemické situace, kdy dochází k lavinovitému a fakticky nijak nekontrolovanému šîrení viru, je bezpochybné prokázání daných skutečností jen velice těžko představitelné. 
smyslu, prokázání řádného plnění krizových opatření jako podmínky pro vznik nároku na plnění z kompenzačních programů atd.).

\section{NÁHRADY PŘI VÝKONU PRÁCE MIMO PRACOVIŠTĚ ZAMĚSTNAVATELE - DE LEGE LATA}

V současné době je poměrně intenzivně řešena otázka náhrad při výkonu práce mimo pracoviště zaměstnavatele / z bydliště zaměstnance; dále bude hovořeno pouze o nákladech na straně zaměstnance, nicméně v kontextu řečeného shora platí uvedené obdobně i pro náklady třetí osoby odlišné od zaměstnavatele, jejíž prostor nebo věci jsou k výkonu práce využívány.

Náklady, jejichž náhrada v souvislosti s výkonem práce mimo pracoviště zaměstnavatele přichází v úvahu, mohou být typově následující:

- zvýšená spotřeba energií a souvisejících služeb (elektrická energie, teplo, vodné a stočné) vyvolaná výkonem práce v bydlišti;

- opotřebení vlastních pracovních prostředků zaměstnance;

- další náklady (napřríklad spotřební materiál typu papír, nucené navýšení datového přenosu internetu, které musel zaměstnanec zajistit kvůli výkonu práce z bydliště a jinak by jej neobstarával, atp.).

Závislá práce je zásadně vykonávána na náklady zaměstnavatele. Jde o jednu ze základních zákonných podmínek (ust. § 2 odst. 2 ZPr). Dle ust. § 346c ve spojení s ust. § 346e ZPr je zdánlivé13 právní jednání, kterým by zaměstnanec chtěl zbavit zaměstnavatele povinnosti poskytnout náhradu výdajů př́slušejících zaměstnanci v souvislosti s výkonem práce.

Náhrada (ust. § 109 odst. 2 ZPr) nemá povahu mzdového plnění. Jedná se o kompenzační nárok, ze kterého zaměstnanec neodvádí daň z př́ijmu a nepodléhá ani odvodům do pojistných systémů.

Náhradu lze podle daňových předpisů poskytnout pouze ve výši skutečně vynaložených nákladů. Náhrada musí odpovídat snížení majetku zaměstnance v důsledku výkonu práce $\mathrm{z}$ bydliště. ${ }^{14}$ Byla-li by náhrada vyšší, v částce přesahující reálné snížení majetku by byla považována za př́jem zaměstnance a musela by být podrobena veřejnoprávním odvodům. Problematická je vedle toho i příliš nízká náhrada, nebot’ ta znamená dluh vůči zaměstnanci a přsestupek z hlediska zákona o inspekci práce.

S ohledem na scházející zákonné ustanovení zavádějící paušalizaci je paušalizace náhrad, s ohledem na nepředvídatelný rozsah nákladů, a tudíž i faktickou nemožnost provést paušalizaci na základě dřívějších skutečných nákladů, fakticky vyloučena.

13 V kontextu právního názoru vyjádřeného Nejvyšším soudem ve věci sp. zn. 29 Cdo 5943/2016 (bod 24 odůvodnění) se lze klonit k tomuto závěru, nebot' v kontextu zvláštní zákonné ochrany postavení zaměstnance zdánlivost právního jednání lépe odpovídá smyslu a účelu zákonné regulace, když zaměstnanci poskytuje lepší výchozí postavení pro uplatnění nároku.

14 V této souvislosti viz stanovisko Generálního finančního ředitelství ze dne 20. listopadu 2019 (Zápis z jednání Koordinačního výboru s Komorou daňových poradců ČR ze dne 20. 11. 2019 [online]. 2019 [cit. 2021 -02-23]. Dostupné na: https://www.financnisprava.cz/assets/cs/prilohy/ZAPIS_KV_KDP_11_2019.pdf). 
Z judikatury Nejvyššího správního soudu (například ve věci sp. zn. 5 Afs 68/2007) se podává, že při určování náhrady za využití vlastních prostředků a prostor zaměstnance by bylo do určité míry možné uvažovat o analogickém postupu jako při určování nákladů osoby samostatně výdělečně činné využívající bydliště k podnikání v ust. §24b zákona o dani z příjmu. K tomu se však Generální finanční ředitelství staví rezervovaně: „Jde-li o paušál za použití vlastního nár̆adí, zařízení a předmětů potřebných pro výkon práce zaměstnance, které by jinak byly odpisovány, uzná se jen do výše, v jaké by zaměstnavatel uplatňoval odpisy srovnatelného hmotného majetku při rovnoměrném odpisování v dalších letech odpisování."15

Jinak řečeno, určení skutečné výše náhrady je poměrně komplikované. A jelikož v daňovém řízení je povinností zaměstnavatele prokázat existenci daňově uznatelných nákladů, je relativně logickým vývodem zaměstnavatelů, že jsou ochotni k poskytnutí náhrady pouze v okamžiku, kdy je ze strany zaměstnance náklad prokázán způsobem odpovídajícím daňovým předpisům.

Tento předpoklad ve spojení se skutečností, že není stanovena žádná zákonná lhůta pro úhradu nákladů, vede k situacím, kdy zaměstnavatel deklaruje ochotu poskytnout náhradu v určité lhůtě po prokázání vzniklých nákladů způsobem odpovídajícím daňovým předpisům, tedy tak, aby je zaměstnavatel mohl převzít do svého účetnictví. Toho však zaměstnanci v řadě případů nejsou schopni či k tomu nejsou pro prŕlišnou komplikovanost ochotni. ${ }^{16}$

\section{NÁHRADY PŘI VÝKONU PRÁCE MIMO PRACOVIŠTĚ ZAMĚSTNAVATELE - DE LEGE FERENDA}

Stávající právní úprava, která nereflektuje některé podstatné momenty, tedy neobstojí z hlediska efektivity. Stejně tak lze mít pochybnost, zda naplňuje obecný princip spravedlnosti. Nabízí se tedy uvažovat o její revizi.

Při formulování pravidel pro poskytování náhrad při přechodném výkonu práce mimo pracoviště zaměstnavatele (pozici odpovídající pozici ii.) režim b) a c) ve smyslu bodu 1. shora) by měly být součástí úvah při hledání proporcionalitě odpovídajícího řešení zejména následující skutečnosti:

- obvyklá výše dodatečných nákladů na straně zaměstnance, které budou vyvolány výkonem práce mimo pracoviště zaměstnavatele;

- fakt, že po dobu výkonu práce mimo pracoviště zaměstnavatele na straně zaměstnavatele nedochází, příp. dochází jen velice nepatrně, ke snížení nákladů na pracovní místo zaměstnance (míněno vybavení a provoz pracovního místa);

- zaměstnanec získává časovou úsporu, nebot' odpadá přeprava do a ze zaměstnání;

- zaměstnanec může získat finanční úsporu, nebot' není třeba hradit náklady přepravy do a ze zaměstnání;

- zaměstnanec může získat finanční úsporu, nebot' má možnost stravování v bydlišti;

15 Tamtéž.

16 Kupř́ikladu v případě vícečlenné domácnosti, zejména pokud došlo v rozhodné době ještě k narození dítěte, je prokázání spotřeby energií v důsledku výkonu práce $\mathrm{z}$ bydliště fakticky nemožné. 
- zvláštní zákonná ochrana postavení zaměstnance si žádá, pokud zaměstnanci svědčí právo na náhradu, aby mu tato byla poskytnuta obratem a bez zbytečné administrativní zátěže, tj. byla reálně dosažitelná.

I kvůli zachování kompaktnosti právní úpravy a jako prevence její pozdější eroze s poukazováním na další atypické situace a výjimky je třeba předem odmítnout řešení, které nepředpokládá poskytnutí náhrady.

Z hlediska efektivity a proporcionality se zdá být vhodné následující řešení:

1. typové rozlišení nákladů ve shodě s uvedeným v bodě 4. na:

a) náklady za využití vlastních pracovních prostředků;

b) náklady za spotřebované energie a za související služby (elektrická energie, voda, teplo);

c) další náklady (navýšení konektivity internetu, spotřební materiál jako papír atd.).

\section{2. stanovení způsobu náhrady:}

a) náhrada za využití vlastních pracovních prostředků

- primární náhrada v paušální výši určené podzákonným právním předpisem. Náhrady by bylo třeba typově rozlišit podle kategorií pracovních prostředků. Představit si lze relativně značnou míru abstraktnosti (například obvyklé kancelářské vybavení atd.). Při určování výše náhrady by bylo třeba vyjít z obvyklé ceny a průměrné doby odpisování takových prostředků. Paušální náhrada by zaměstnanci náležela za každou započatou hodinu výkonu práce za využití takových pracovních prostředků. Pro výplatu náhrady by byla stanovena splatnost shodná jako pro mzdu a plat, tzn. náhrada by byla splatná do konce kalendářního měsíce následujícího po měsíci, kdy byla práce mimo pracoviště zaměstnavatele vykonána;

- pokud by nebyly skutečně vynaložené náklady zcela kryty paušální náhradou, na základě písemného prohlášení zaměstnance v předepsané lhůtě by bylo možné zaměstnanci uhradit doplatek ve výši rozdílu mezi paušální náhradou a skutečně vynaloženými náklady za podmínky prokázání vynaložených nákladů způsobem odpovídajícím daňovým předpisům tak, aby mohla být bez dalšího vyplacená náhrada vzata za uznatelný daňový náklad zaměstnavatele. Doplatek by byl splatný do konce kalendářního měsíce následujícího po měsíci, ve kterém by byly řádně náklady prokázány.

b) náhrada za spotřebované energie a za související služby

- primární náhrada v paušální výši určené podzákonným právním předpisem, kdy by výše náhrady vycházela z průměrných cen energií a z obvyklé spotřeby. Paušální náhrada by byla určena hodinově. Zaměstnanci by svědčilo právo na náhradu za každou započatou hodinu výkonu práce. Pro výplatu náhrady by byla stanovena splatnost shodná jako pro mzdu a plat, tzn. náhrada by byla splatná do konce kalendářního měsíce následujícího po měsíci, kdy byla práce mimo pracoviště zaměstnavatele vykonána;

- pokud by nebyly skutečně vynaložené náklady zcela kryty paušální náhradou, na základě písemného prohlášení zaměstnance v předepsané lhůtě by bylo možné zaměstnanci uhradit doplatek ve výši rozdílu mezi paušální 
náhradou a skutečně vynaloženými náklady za podmínky prokázání vynaložených nákladů způsobem odpovídajícím daňovým předpisům tak, aby mohla být bez dalšího vyplacená náhrada vzata za uznatelný daňový náklad zaměstnavatele. Doplatek by byl splatný do konce kalendářního měsíce následujícího po měsíci, ve kterém by byly řádně náklady prokázány.

\section{c) další náhrada}

- primární náhrada v zaměstnancem prokázané skutečné výši vynaložených nákladů. Pro výplatu náhrady by byla stanovena splatnost shodná jako pro mzdu a plat, tzn. splatná by byla do konce následujícího kalendářního měsíce následujícího po řádném prokázání vynaložených nákladů;

- nebude-li zaměstnanec na základě svého prohlášení schopen či ochoten způsobem odpovídajícím daňovým předpisům prokázat skutečnou výši vynaložených nákladů, náhrada by se poskytovala ve výši obvyklé, tj. ve výši určené podle obvyklých cen $\mathrm{v}$ době, kdy zaměstnanec náklady vynaložil. $\mathrm{V}$ tomto př́ípadě by zaměstnanec prokazoval pouze to, že věci či služby k výkonu práce použil. Pro výplatu náhrady by byla stanovena splatnost shodná jako pro mzdu a plat, tzn. splatná by byla do konce následujícího kalendářního měsíce následujícího po řádném prokázání využití prostředků či služeb.

V případě obvyklé domácí kancelářské práce při využití vlastních pracovních prostř̌edků by se za směnu pohybovala výše takto určené náhrady pravděpodobně v řádech desetikorun.

Pro př́ípad výkonu práce $\mathrm{z}$ bydliště, ke kterému zaměstnanec nemá dispoziční oprávnění (viz shora), a věcí v něm, se nabízí vytvořit konstrukci chránící dobrou víru zaměstnavatele. Tedy uzavírá-li zaměstnanec dohodu o výkonu práce z bydliště, platí, že mu svědčí dostatečné oprávnění $\mathrm{k}$ udělení svolení $\mathrm{k}$ užití prostor a věcí v nich pro výkon práce.

Náhrada by se poskytovala zaměstnanci s tím, že by třetí osobě vůči zaměstnanci svědčil nárok na peněžité plnění ve výši náhrady, na kterou zaměstnanci vůči zaměstnavateli vzniklo právo.

Taková konstrukce se zdá udržitelná s ohledem na předpokládaný důvěrný vztah zaměstnance a osoby, u níž má bydliště z titulu společného žití, a nikoli z titulu nájemního nebo jiného obdobného vztahu.

\section{ZÁVĚREČNÉ POZNÁMKY}

Naznačené problematické momenty stávající právní úpravy ve vztahu $\mathrm{k}$ výkonu práce mimo pracoviště zaměstnavatele jsou jen jedny z mnoha. Vedle již zmíněné problematiky bezpečnosti a ochrany zdraví při práci, odpovědnosti, včetně odpovědnosti za pracovní úrazy a nemoci z povolání, pravidel organizace práce, ochrany osobních údajů atd. se dále jedná kupříkladu o využívání webových kamer ke kontrole plnění pracovněprávních povinností zaměstnance, o využití institutů přesčasové práce 
či pracovní pohotovosti při výkonu práce mimo pracoviště zaměstnavatele či o veřejnoprávní aspekty zaměstnaneckých benefitů.

Celková neutěšenost a neúplnost vnímání věci je relativně dobře patrná u jednoho z obvyklých zaměstnaneckých benefitů, jímž je příspěvek na stravování.

Podmínky, za kterých se takový benefit poskytuje, určuje zaměstnavatel; necháme-li stranou dohodu zaměstnavatele a zaměstnance o poskytování takového benefitu. Při určování pravidel pro poskytování příspěvků je zaměstnavatel v zásadě pouze rámcově omezen příkazem zajistit rovné zacházení a zákazem diskriminace.

Z hlediska daňové uznatelnosti je rozhodující, aby byly splněny podmínky podle ust. § 24 odst. 2 písm. j) bod 4 zákona o dani z př́ijmu a osvobození od daně z příjmu na straně zaměstnance, stejně jako dalších veřejnoprávních odvodů. Dle odkazovaného ustanovení je podmínkou, že „přítomnost zaměstnance v práci během této stanovené směny trvá alespoň 3 hodiny“.

Výklad stavící na vyjádření generálního finančního ředitelství ${ }^{17}$ směřuje tím směrem, že uvedená podmínka bude formálně splněna $\mathrm{v}$ př́ípadě režimu b) ve smyslu bodu 1 .

$\mathrm{K}$ tomu je dodáváno, že v případě čistého režimu c) ve smyslu bodu 1 práce rozvržená zaměstnancem neodpovídá definici směny ve smyslu ust. $\$ 78$ odst. 1 písm. c) ZPr. To vede $\mathrm{k}$ závěru, že v tomto případě by se o daňově uznatelný výdaj nejednalo. V souvislosti s řečeným je navrhováno v rámci režimu c) ve smyslu bodu 1 určit pevnou část denní doby (v délce alespoň 3 hodiny), kdy zaměstnanec bude vykonávat práci (bude dostupný pro kolegy atd.), de facto na 3 hodiny denně uplatnit režim b) ve smyslu bodu 1 a ve zbytku stanovené týdenní pracovní doby uplatnit režim c) ve smyslu bodu 1.

Formálně, bez zohlednění smyslu předmětné právní úpravy, může takový výklad obstát. Účelem zákonné úpravy je však reagovat na předpokládané navýšení nákladů na stravování při výkonu práce na pracovišti zaměstnavatele oproti nákladům, které by zaměstnanci na stravování vznikly při pobytu v bydlišti. Budeme-li předpokládat, že při výkonu práce z bydliště k navýšení nákladů nedochází, pak institut v tomto případě nemůže plnit svůj účel a neměl by být použit (a to ani pro režim b) ve smyslu bodu ii.) shora); vyloučení aplikace předmětné právní úpravy prostřednictvím teleologické redukce však z druhé strany koliduje s právní jistotou.

Uzavřít lze s tím, že s ohledem na specifičnost jednotlivých pozic se pravděpodobně, je-li cílem efektivní, rozumně uplatnitelná, spravedlivá a srozumitelná právní úprava, do budoucna nevyhneme typizování pracovních režimů a komplexnímu vymezení jednotlivých kategorií, včetně právní úpravy náhrad při výkonu práce mimo pracoviště zaměstnavatele.

doc. JUDr. Jakub Morávek, Ph.D.

Právnická fakulta Univerzity Karlovy

moravek@prf.cuni.cz

17 V této souvislosti viz stanovisko Generálního finančního ředitelství ze dne 20. listopadu 2019 (c.d.). 